\title{
The Discourse and Practice of Islamic Family Law in Indonesia
}

\section{Nurrohman Syarif}

Associate Professor, State Islamic University (UIN) Sunan Gunung Djati, Bandung

\section{ABSTRACT}

Family law is the most powerful law practiced in Islamic history, but this does not mean that it avoids the demands of changing times. Today, there are no less than thirteen problems related to family law that have arisen in the Muslim world. This problem arises not only because of demands for changing times, but also because of efforts to unify, codify and legislate Islamic law in a number of Muslim countries. This problem requires not only solutions but also reforms. This study aims to examine the model of understanding, practicing, reforming and transforming Islamic law in Indonesia and its impact on the position of standard classical fiqh books and the independence of judges in the Religious Courts. This research is a non-doctrinal normative qualitative research type. This study found a variety of models in the exploration, practice and reform of family law in Indonesia. The impact of the reform and transformation of family law in Indonesia is that classical fiqh books are no longer used as the main reference and the Religious Court System is closer to the civil law system. However, the reform and transformation of family law in Indonesia did not reduce the independence of religious judges in exploring and discovering more contextual Islamic law.

Keywords

Islamic Law, Reform, Religious Courts, Indonesia, Legislation

Article Received: 10 August 2020, Revised: 25 October 2020, Accepted: 18 November 2020

\section{Introduction}

Change is a natural law so that in this world basically nothing is permanent and eternal, everything changes. Likewise, Islamic law, although this law contains a sacred content because it is believed to come from God, the way Muslims understand and the methods used to explore it are constantly evolving in line with the changing times. The Prophet Muhammad SAW realized these developments and changes from the beginning. He not only encourages the judges to perform ijtihad (individual reasoning) but also predicts that in every century there will always be reformers of their religion (Abu Daud, juz II, tt: 240). Therefore, it is understood if in Islamic law there are rules for changing laws to occur due to changes in time and space (taghayyurul ahkam bi al-taghayyuril azminah wa al-amkinah). However, in order for this change not to run wild and remain under control, the scholars have formulated a number of principles, rules and objectives of Islamic law itself, so that the change does not deviate from the goals to be achieved by Islamic law.

There are at least six principles that can be used to develop Islamic law, namely: (1) eliminating difficulties (QS 22: 78 and QS 2: 286). minimizing the rules (QS 66; 1). (3) in line with benefit (QS 21 al-Anbiya: 107) (4) realizing equitable justice (QS 5; 8). (5) prioritizing reason over religious texts (QS 17: 36) (6) each person bears his own responsibility. (QS 6: 164).

In line with the principles of fostering Islamic law, in fiqh there are also five basic principles or legal maxims, namely: (1) All problems depend on their objectives. (al-umur bimaqashidiha) (2). This harm must be eliminated (al-dlarar yuzalu) (3) The custom can be made into law. (al-adat muhakkamat) (4) That conviction cannot be dispelled with doubt. (al-yaqin la yuzalu bi alsyak) (5) The difficulty can attract convenience (al-masyaqqh tajlibu al-taisir). This basic principle by Imam Muhammad Izzudin bin Abdis Salam is summarized into the rule of "Rejecting damage and attracting benefit" (Ash Shiddieqy, 1975: 73-92)

Apart from having a number of principles, Islamic law also has a purpose (Auda, 2007). Family law in Islam exists with the aim of protecting three basic human rights, namely: property, life and to obtain offspring / self-respect (Hosseini et al, 2013: 143) In Islamic history, although family law is the most strongly practiced law (Schacht, 1983: 83 ), but this does not mean that it able to avoid the 
demands of change in dealing with problems that arise from the times. Today, there are no less than thirteen problems related to family law that have arisen in the Muslim world. (Mahmood, 1987: 11,12). Problems arise not only because of demands for changing times, but also because of efforts to unify, codify and legislate Islamic law in a number of Muslim countries as a result of the influence of the civil law system.

In its long history, Islamic law is actually not the same as the legal system that has existed in other countries, namely; civil or common law system. Islamic law is the third system known as juristic law (legal expert law). Because it is compiled and developed by private specialists, not by the state. Law science and scholarly handbooks play a legislative role and also have the power of law. (Black, Ismaeili and Hosen, 2013: xi). In other words, Islamic law with its various variations develops outside state institutions (Alam, 2007). Therefore, the idea of unification, codification and legislation as proposed by Ibn Muqaffa (d. 139/756) was not popular in classical times (Schacht, 1983: 49).

This study aims to examine; (1) models of understanding, practice, reform and transformation practiced in Indonesia; (2) the impact of reform and transformation on standard classical fiqh books which are used as references in the Religious Courts in Indonesia and (3) the impact of reform and transformation on the independence of judges in exploring Islamic law.

This issue is important to raise because with the assumption that the model of reform and transformation of Islamic law is not singular, Indonesia deserves to have its own model in developing Islamic law with reference to its own culture and the objectives of Islamic law and the constitution. The view that it is impossible for Muslims in Indonesia to fully implement Islamic law because Indonesia is not an Islamic state cannot be accepted.

This is because a study proves that Indonesia is no less Islamic than other Muslim countries which formally declare themselves an Islamic state. (Rehman and Askari, 2010: 1-37). The contribution of the formal constitutional declaration in realizing the formation of an
Islamic state is only five percent. Because the Islamic weight of a country is more measured by the qualifications and legitimacy of its leaders and the governance of its government as a whole (Abdul Rauf, 2015: 58).

So, this article is actually an effort to support the views of a number of experts, such as Farid $F$ Mas'udi (Mas'udi, 2011) and Hasbullah Bakri (Bakri, 1984: 32) who state that Indonesia is, substantively, an Islamic country even though it does not make Islam the basis of the state. This article also strengthens Hazairin's view on the need for Indonesian-style law or Hasbi Ashidieqy's view on Indonesian Fiqh. (Lubis, 1997: 33 -92). This article also strengthens the theory linking Islamic law with faith or what is known as the credo theory. (Praja, 2009). This article rejects the views of Islamism groups that tend to be theocratic, exclusive and authoritarian in interpreting Islam so that it is not suitable to be developed in a democratic era. (Tibi, 2012: 1). So, the originality or novelty of this article does not lie in the substance being studied but in the way the existing data or facts are reviewed and linked to developments in Indonesia. This research is a continuation of previous research which is also related to the theme of transformation and integration of Islamic law into national law.

\section{Methodology}

This research is a library research related to legal aspects, so it can be called normative research (Soekanto and Mamudji, 2001: 13-14). But it can also be called non-doctrinal qualitative legal research because it includes problem analysis, policy and reform. (Dobinson and Johns, 2007: 20). This article is based on the assumption that Islamic law actually has an unchanging essence, namely realizing justice, benefit, bringing mercy and containing wisdom. (Ibn Qayyim, tt: 37).

This is what is called the ideal concept of the perfect, flawless sharia, because it is divine. (Abou El-Fadl, 2004: 34). However, as sharia developed, in history there are classical sharia, historical sharia and contemporary sharia. (Otto, 2010: 25-26). Classical sharia is a set of rules, principles and cases collected by the jurists during the two centuries after the death of the Prophet Muhammad, in order to find out what is actually 
God's will. Sharia in this case can be found in the works of classical scholars in the dominant schools of thought, therefore it is more concrete. Historical sharia includes the principles, rules, cases and interpretations developed by the jurists and transmitted from time to time throughout the Islamic world over a period of more than a thousand years. Contemporary sharia is the sharia understood by Muslims today all over the world. In this context, the sharia is incarnate in its plural form.

Even though there are dynamics and plurality in the development of sharia, it has a purpose. The essence of sharia and its purpose is relatively unchanged. According to classical and contemporary scholars, sharia or Islamic law aims to protect five or six things, namely, religion, life, property, reason, descent / family and honor (Auda, 2007).

The study of reform and transformation of family law is divided into several stages. The first discusses the model of excavating, practicing and reforming family law in the Muslim world in general; the second discusses the model of excavation, practice, reform and transformation of family law in Indonesia; third, discussing the impact of reform and transformation on classical fiqh books which are used as references for religious courts in Indonesia; fourth, the impact of reform and transformation on the independence of Religious Court judges in deciding cases. Lastly are the conclusions and recommendations.

\section{Results and Discourses}

\section{Model of Understanding, Practicing, Reforming and Transforming Islamic Law}

The model of transformation and integration of Islamic law into national law in a number of countries cannot be separated from the way in which Islamic law is explored, formulated and practiced. Different ways of exploring, practicing and formulating have resulted in differences in Muslims in transforming Islamic law into national law.

Therefore, the discussion about the transformation model needs to be preceded by a discussion about the model of extracting and practicing Islamic law. Seen in its history, in general, the model of extracting Islamic law can be carried out through the model of bayani, irfani and burhani. In the bayani excavation model, sharia or Islamic law is extracted from religious text sources using the istinbath or istidlal method through linguistic approach. Truth is measured by the principle of correspondence. The source of irfani excavation model is intuition, the method is kasyf or illumination, the approach is psycho-gnostic. The truth is measured through inter-subjective. The source of the burhani excavation model is ratio, the method used is analytical discourse, the approach is logic and the truth is measured by the principle of coherence or consistency. (Syarif, 2019: 347-359)

Table I. Model for Understanding Islamic Law

\begin{tabular}{|c|c|c|c|}
\hline $\begin{array}{l}\text { Type/ } \\
\text { model }\end{array}$ & Source & Method and approach & $\begin{array}{c}\text { The validity of } \\
\text { truth }\end{array}$ \\
\hline Bayani & $\begin{array}{l}\text { Religious } \\
\text { texts }\end{array}$ & Legal reasoning with a linguistic approach & Correspondence \\
\hline Irfani & Intuition & $\begin{array}{c}\text { Divine radiance with a psychological } \\
\text { approach (psycho-gnostic) }\end{array}$ & Inter-subjective \\
\hline Burhani & Ratio & Analytical discourse through logical approach & $\begin{array}{l}\text { Coherence or } \\
\text { consistency }\end{array}$ \\
\hline
\end{tabular}

All models of extracting Islamic law can be used in order to realize the objectives of Islamic law. In family law, the objectives of Islamic law can be described as follows (Hosseini, et al. 2013: 143 


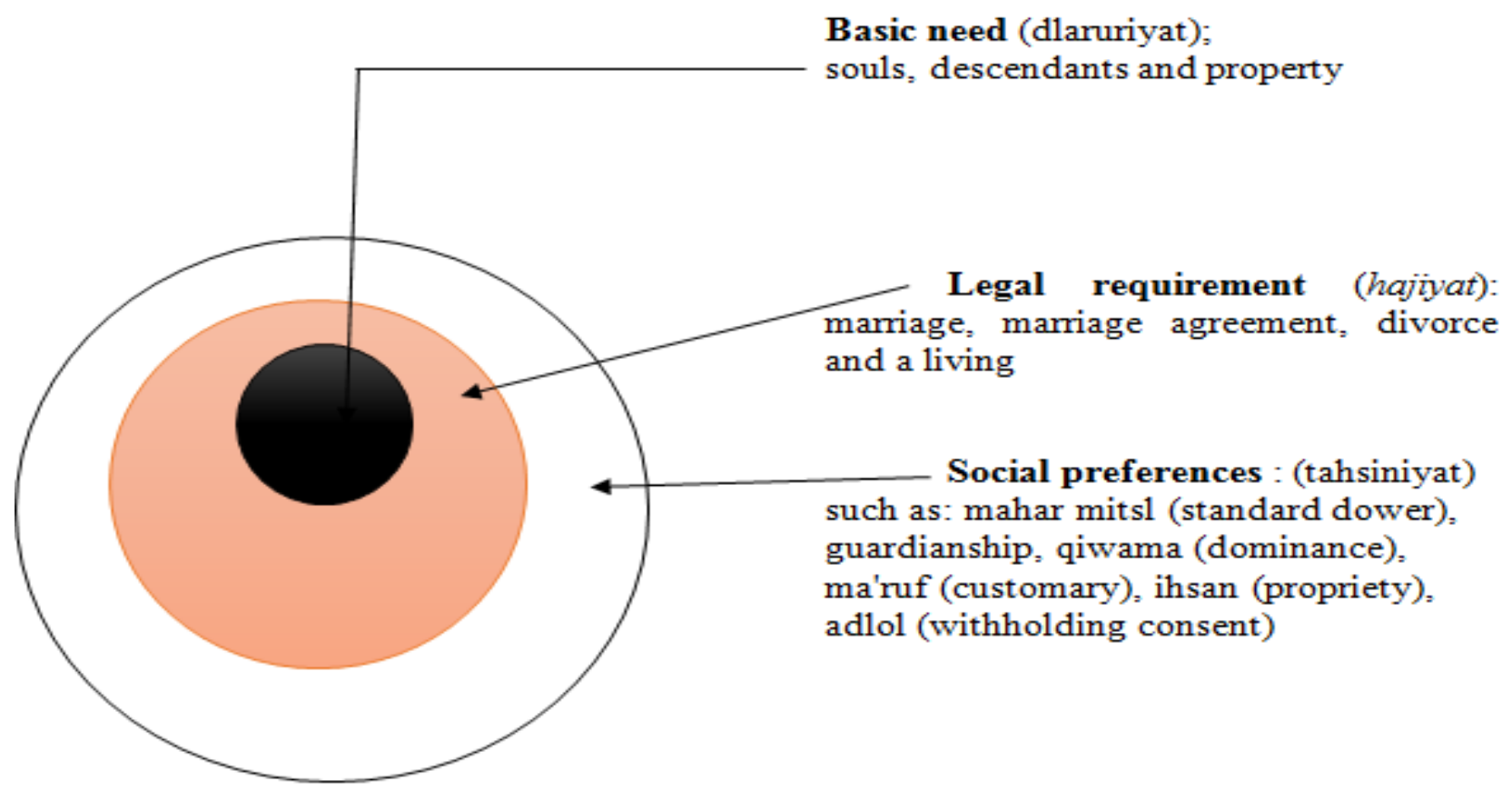

Figure 1. Maqashid Sharia in Family Law

The prohibition of polygamy in the form of polygyny and polyandry in a number of Muslim countries is a form of progressive reform resulting from the burhani excavation model. The prohibition on polygamy is the result of a process of discourse analysis (analytical discourse) through a logical approach by looking at the historical background, process and textual guidance, the function of discourse in the text of the Koran and the effort to explore the unspeakable. Likewise, the prohibition against slavery. (Ridwan, 2013)

Table 2. Examples of Burhani Model in Excavating Islamic Law (Polygyny)

\begin{tabular}{|c|c|c|c|c|c|}
\hline & \multicolumn{3}{|c|}{ Background, process and instructions (dilalah) } & $\begin{array}{c}\text { The function of } \\
\text { discourse in the } \\
\text { Qur'an }\end{array}$ & $\begin{array}{c}\text { The } \\
\text { unspeakable }\end{array}$ \\
\hline $\begin{array}{c}\text { Polygyny / } \\
\text { Polygamy }\end{array}$ & $\begin{array}{c}\text { Polygyny } \\
\text { was } \\
\text { practiced } \\
\text { indefinitely } \\
\text { before Islam }\end{array}$ & $\begin{array}{c}\text { Polygyny } \\
\text { restriction to a } \\
\text { maximum of } \\
\text { four wives who } \\
\text { are treated } \\
\text { fairly }\end{array}$ & $\begin{array}{c}\text { The husband's } \\
\text { impossibility } \\
\text { to be fair }\end{array}$ & $\begin{array}{c}\text { The final } \\
\text { direction of the } \\
\text { marriage norm } \\
\text { is monogamy. }\end{array}$ & $\begin{array}{c}\text { Prohibition } \\
\text { against } \\
\text { polygamy. }\end{array}$ \\
\hline
\end{tabular}

Table 3. Example of the Burhani Model in Exploring Islamic Law (Slavery)

\begin{tabular}{|c|c|c|c|c|c|}
\hline \multirow{8}{*}{ Slavery } & \multicolumn{3}{|c|}{ Background, process and instructions (dilalah) } & $\begin{array}{c}\text { The function of } \\
\text { discourse in the } \\
\text { Qur'an }\end{array}$ & $\begin{array}{c}\text { The } \\
\text { unspeakable }\end{array}$ \\
$\begin{array}{c}\text { Slavery is } \\
\text { part of the } \\
\text { pre-Islamic } \\
\text { socio- } \\
\text { economic }\end{array}$ & $\begin{array}{c}\text { Liberation of } \\
\text { slavery is } \\
\text { recommended } \\
\text { through various } \\
\text { ways }\end{array}$ & $\begin{array}{c}\text { Slavery is } \\
\text { directed so that } \\
\text { it does not } \\
\text { become a part } \\
\text { of the socio- }\end{array}$ & $\begin{array}{c}\text { The discourse of } \\
\text { slavery is studied } \\
\text { as limited as } \\
\text { historical } \\
\text { evidence. }\end{array}$ & $\begin{array}{c}\text { The ultimate } \\
\text { goal is the } \\
\text { elimination of } \\
\text { all forms of } \\
\text { slavery }\end{array}$ \\
\hline
\end{tabular}




\begin{tabular}{|l|l|l|l|l|l|}
\hline system & & $\begin{array}{c}\text { economic } \\
\text { system }\end{array}$ & & \\
\hline
\end{tabular}

In general, there are three models of implementation or practice of Islamic law 1) exclusive textual model 2) inclusive substantive and 3) a combination model of the two (Nurrohman, 2019: 347-359). In general, Islamic law reform in the Islamic world can also be divided into two, namely: extra doctrinal reform, intra doctrinal. Reformation referred to here is all activities related to change and renewal.

Table 4. Islamic Law Reform Model

\begin{tabular}{|c|c|c|}
\hline Model & Description & Example \\
\hline $\begin{array}{c}\text { Extra doctrinal } \\
\text { reform }\end{array}$ & $\begin{array}{c}\text { Reformation is carried out by } \\
\text { reinterpreting the Al-Qur'an and } \\
\text { Sunnah texts. This is because this } \\
\text { renewal has no reference in the } \\
\text { doctrine of classical figh. } \\
\text { (Classical sharia) }\end{array}$ & $\begin{array}{c}\text { In Tunisian law, divorce only falls } \\
\text { and is legal when it occurs in court. } \\
\text { According to the Turkish Civil Code } \\
\text { 1926, polygamy is completely } \\
\text { prohibited and if it occurs then the } \\
\text { marriage is declared invalid. }\end{array}$ \\
\hline \multirow{5}{*}{$\begin{array}{c}\text { Intra doctrinal } \\
\text { reform }\end{array}$} & $\begin{array}{c}\text { Reform is carried out by taking a } \\
\text { view that is contained within one } \\
\text { school but outside the schools that } \\
\text { are commonly used in one area. } \\
\text { The methods used are talfiq } \\
\text { (amalgamation), tahyir (choosing } \\
\text { from various schools of thought) } \\
\text { and siyasah syariyyah (political } \\
\text { law) for the benefit of the citizens. }\end{array}$ & $\begin{array}{c}\text { Examples of countries implementing } \\
\text { this reform model include: } \\
\text { Indonesia, Malaysia, Morocco, } \\
\text { Algeria, Iraq Pakistan }\end{array}$ \\
& & \\
\end{tabular}

Viewed from the perspective of gender equality and justice, there are progressive and nonprogressive Islamic legal reforms. Reform is called progressive when considering gender sensitivity. Among the Muslim countries that are carrying out progressive reforms in family law is Somalia. (Huda, 2017)

Although family law reform can be broadly divided into two, namely; intra and extra doctrinal reform, but the methods and techniques vary. There are at least seven methods used by the Islamic world, namely: 1) making all schools of thought in Islam equal (musawat al-madzahib 2) istihsan 3) masalih al-mursalah. 4) siyasah syar'iyah 5) istidlal 6) legislation 7) codification. There are five techniques used, namely: 1) ijma 2) qiyas 3) ijtihad individually and collectively. 4) eclectic choices. 5) merging two legal rules from different schools of thought into one / talfiq.
(Mahmood, 1987: 13). Tahayur (choosing a suitable opinion) and talfiq (combining two or more opinions taken from various schools of thought), in the classical fiqh tradition especially among Syafiiyah are considered unethical. Because it is considered to make it easier or to play with religion.

Etymologically, transformation means a change in shape, appearance, format and character. This change can be a whole or it can be a specific part. It can also happen by evolution or revolution (Abdul Hakim, 2018: 60-63). What is meant by transformation here is the change of fiqh into national law or law. The model of transforming sharia into national law can be divided into three, namely substantive progressive, normative adaptive, and symbolic attributive. (Nurrohman et al, 2018: 59) 
Table 5. Model of Transformation of Islamic Law into National Law

\begin{tabular}{|l|l|l|}
\hline Model & Description & Example/ note \\
\hline $\begin{array}{l}\text { Substantive } \\
\text { pprogressive }\end{array}$ & $\begin{array}{l}\text { Transformation is called substantive if the } \\
\text { substance of Islamic law, namely justice, } \\
\text { benefit and protection of human rights has } \\
\text { been accommodated in the national legal } \\
\text { system. }\end{array}$ & $\begin{array}{l}\text { The Indonesian Constitution } \\
\text { has adopted the principles of } \\
\text { Islamic law based on the } \\
\text { research of Harun Nasution } \\
\text { and Masdar Farid Mas'udi }\end{array}$ \\
\hline $\begin{array}{l}\text { Normative } \\
\text { (adaptive) }\end{array}$ & $\begin{array}{l}\text { The transformation of Islamic law into } \\
\text { national law occurs when the norms } \\
\text { contained in Islamic law are accommodated } \\
\text { and made into national legal norms. }\end{array}$ & $\begin{array}{l}\text { Most of the Islamic legal } \\
\text { norms on Marriage have been } \\
\text { accommodated in Law No. } \\
1 / 1974 \text { on Marriage. }\end{array}$ \\
\hline $\begin{array}{l}\text { Attributive or } \\
\text { symbolic }\end{array}$ & $\begin{array}{l}\text { Symbolically or attributively, Islamic law has } \\
\text { changed into national law if the attributes or } \\
\text { symbols of Islamic law such as sharia, al-adl } \\
\text { (fair), hikmah (wisdom), zakat, waqf and so } \\
\text { on are accommodated in national law. }\end{array}$ & $\begin{array}{l}\text { There are several attributes } \\
\text { that symbolically denote } \\
\text { Islamic law such as the terms } \\
\text { zina, waqaf and zakat, } \\
\text { although the contents may } \\
\text { differ from what some } \\
\text { scholars want. }\end{array}$ \\
\hline
\end{tabular}

So, in each model there are three variants, as illustrated in the following table.

Table 6. Models for Excavation, Practice, and Transformation
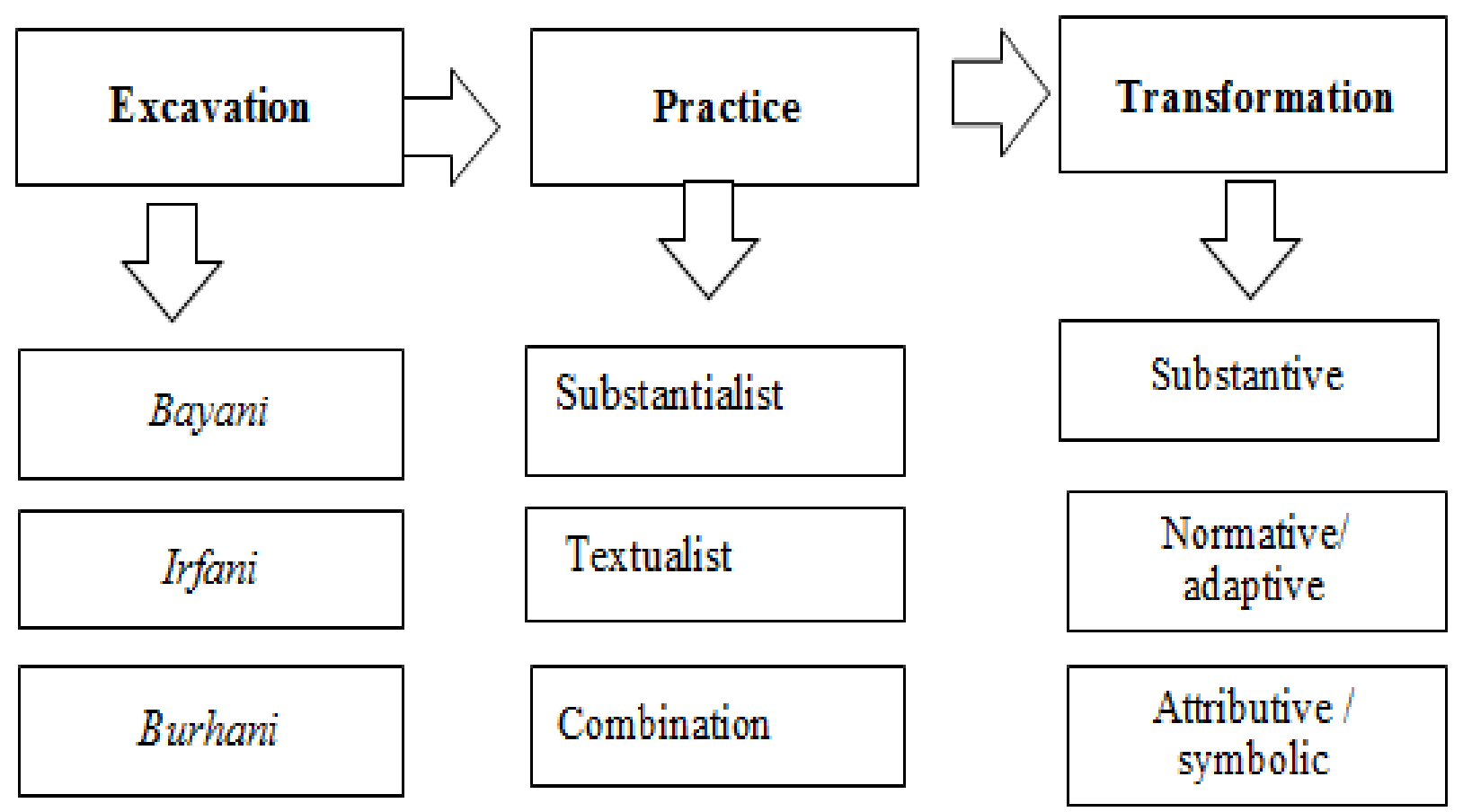

Source: Nurrohman et al, 2018: 59

\section{Model of Family Law Reform and Transformation in Indonesia}

The model of reform and transformation of family law in Indonesia has historically been influenced by the theory and politics of law adopted by the government or the state. For example, since 1855 , the Receptio in complexu theory has been used by the Religious Courts in resolving family disputes among Muslims. The receptie theory then replaced it in 1929. However, since Indonesia declared its independence, another theory has 
emerged called the Receptio a contrario. This theory is then strengthened by a theory called the positivation of Islamic law. (Syarif, 2019)

Table 7. Family Law Theory Practiced in Indonesia

\begin{tabular}{|c|c|c|c|}
\hline Name & Description & Implication & Notes or references \\
\hline $\begin{array}{l}\text { Receptio in } \\
\text { complexu }\end{array}$ & $\begin{array}{l}\text { Muslims must obey and } \\
\text { follow the norms of sharia } \\
\text { as a consequence of their } \\
\text { religion. }\end{array}$ & $\begin{array}{l}\text { Sharia norms are } \\
\text { immediately applied to } \\
\text { Muslims without waiting } \\
\text { for the norms to be } \\
\text { accepted or not by } \\
\text { customs. }\end{array}$ & $\begin{array}{l}\text { Practiced in the } \\
\text { Religious Courts } \\
\text { since } 1855\end{array}$ \\
\hline Receptie & $\begin{array}{l}\text { In civil disputes between } \\
\text { fellow Muslims, the } \\
\text { Islamic Judge shall decide } \\
\text { with customary law if the } \\
\text { customary law so requires. }\end{array}$ & $\begin{array}{l}\text { The application of sharia } \\
\text { norms depends on } \\
\text { customary acceptance of } \\
\text { it. }\end{array}$ & $\begin{array}{l}\text { Colonial } \\
\text { government } \\
\text { reference } \\
1929 .\end{array}$ \\
\hline $\begin{array}{l}\text { Receptio } \\
\text { contrario }\end{array}$ & $\begin{array}{l}\text { For Muslims, Islamic law } \\
\text { must be applied to them. }\end{array}$ & $\begin{array}{l}\text { Customary law can be } \\
\text { applied if it does not } \\
\text { contradict Islamic law. }\end{array}$ & \\
\hline $\begin{array}{l}\text { Positivati-on } \\
\text { of Islamic law }\end{array}$ & $\begin{array}{l}\text { Islamic law has, in } \\
\text { principle, become positive } \\
\text { law for Indonesian } \\
\text { Muslims }\end{array}$ & $\begin{array}{l}\text { The validity of Islamic } \\
\text { law is not determined by } \\
\text { acceptance of customary } \\
\text { law. }\end{array}$ & $\begin{array}{l}\text { The references to } \\
\text { this theory are: } \\
\text { Law No.1 / 1974 } \\
\text { on Marriage }\end{array}$ \\
\hline
\end{tabular}

If seen from the form of family law reform carried out by Indonesia, the reforms carried out by Indonesia tend to be intra-doctrinal reform by taking a view that is outside the schools commonly used in one region of Indonesia, namely the Syafii school of thought but still within the principles of the Islamic schools of thought. The methods used are talfiq (amalgamation), tahyir (choosing from various schools of thought) and siyasah syariyyah (political law) for the benefit of the citizens. Prior to the existence of the Compilation of Islamic Law (KHI), the reference source for judges at the Religious Courts in Indonesia was only 13 books which generally had the Syafii school of thought. But after the existence of KHI, the book references used were 38 books with a more diverse variety of schools.

At least five reforms were found in family law contained in the KHI. Among these are: (1) a person can marry at least 16 years of age for a woman and 19 years for a man as stated in Article 15 paragraph 1 KHI. (2) Whereas divorce is legal if it is carried out before a Religious Court hearing as stated in Article $115 \mathrm{KHI}$. In other words, a divorce that is not carried out in court is an illegal divorce. (3) In the Law of Inheritance there is the term Substitute Inheritance of an Inheritance who has died, namely in Article 185 KHI. (4) Girls as well as boys can prevent a sibling's inheritance as stated in Article 174 paragraph (2). (5) Regarding wills, in the KHI, there is the term compulsory wills for adopted children or adoptive parents, namely in Article 209 KHI.

This provision is different from the provisions contained in the classical fiqh book, which means that in the KHI there are reforms that are adjusted to the sense of justice and benefit for the Muslims in Indonesia. Apart from this renewal, there are also opinions that do not follow the provisions of the jumhur ulama (majority of scholars) such as marrying a pregnant woman as contained in Article 53 paragraph (1) of the KHI. Article 183 KHI reads: In the case of inheritance, the heirs can agree to make peace in the distribution of the inheritance, after each realizes their share. (Nurrohman, et al, 2018) 
Table 8. Reform in Compilation of Islamic Law

\begin{tabular}{|c|c|c|c|}
\hline Number & DESCRIPTION & ARTICLE & NOTES / EXPLANATION \\
\hline 1 & $\begin{array}{l}\text { That a person can be married } \\
\text { at least } 16 \text { years old for a } \\
\text { woman and } 19 \text { years old for a } \\
\text { man }\end{array}$ & $\begin{array}{l}\text { Article } 15 \\
\text { paragraph } 1 \\
\text { KHI }\end{array}$ & $\begin{array}{l}\text { For the benefit of the family and household, } \\
\text { marriage may only be performed by a } \\
\text { prospective bride who has reached the age } \\
\text { stipulated in Article } 7 \text { of the Law. Law No. } 1 \\
\text { of } 1974 \text {, namely that the prospective } \\
\text { husband is at least } 19 \text { years old and the } \\
\text { prospective wife is at least } 16 \text { years old. The } \\
\text { age for marriage between a man and a } \\
\text { woman was then changed based on the } \\
\text { decision of the Constitutional Court in } \\
\text { December } 2018 \text {, namely that both men and } \\
\text { women must have reached the age of } 19 \text {. }\end{array}$ \\
\hline 2 & $\begin{array}{l}\text { Whereas a divorce is legal if it } \\
\text { is carried out before a } \\
\text { Religious Court hearing. }\end{array}$ & $\begin{array}{l}\text { Article } 115 \\
\text { KHI }\end{array}$ & $\begin{array}{l}\text { reads: "Divorce can only be carried out } \\
\text { before a Religious Court hearing after the } \\
\text { Religious Court has tried and failed to } \\
\text { reconcile the two parties". } \\
\text { In other words, a divorce that is not carried } \\
\text { out in a court hearing is an illegal divorce. }\end{array}$ \\
\hline 3 & $\begin{array}{l}\text { In the Law of Inheritance, } \\
\text { there is the term Substitute } \\
\text { Inheritance for a deceased } \\
\text { Inheritance }\end{array}$ & $\begin{array}{l}\text { Article } 185 \\
\text { KHI }\end{array}$ & $\begin{array}{l}\text { Heirs who die earlier than the heir, then } \\
\text { their position can be replaced by their } \\
\text { children. }\end{array}$ \\
\hline 4 & $\begin{array}{l}\text { Girls as well as boys can } \\
\text { prevent sibling's inheritance. }\end{array}$ & $\begin{array}{l}\text { Article } 174 \\
\text { paragraph } 2\end{array}$ & $\begin{array}{l}\text { Article } 174 \text { paragraph (2) reads: if all heirs } \\
\text { are present, only children, fathers, mothers, } \\
\text { widows or widowers are entitled to } \\
\text { inheritance. }\end{array}$ \\
\hline 5 & $\begin{array}{l}\text { In the KHI, there is the term } \\
\text { wills compulsory for adoptive } \\
\text { children or adoptive parents. }\end{array}$ & $\begin{array}{l}\text { Article } 209 \\
\text { KHI }\end{array}$ & $\begin{array}{l}\text { for adoptive parents who do not receive a } \\
\text { will is given a mandatory will of up to } 1 / 3 \text { of } \\
\text { the wills of their adopted children. } \\
\text { (paragraph } \\
\text { Adopted children who do not receive a will, } \\
\text { be given a mandatory will of up to } 1 / 3 \text { of the } \\
\text { inheritance of their adoptive parents. }\end{array}$ \\
\hline
\end{tabular}

\section{The Impact of Reformation and transformation on the Position of Classical Fiqh Books}

Through the Circular of the Bureau of Religious Courts Number B / 1/735 dated February 18, 1958, judges were advised to examine and decide cases based on the 13 books of figh. Then, through a presidential instruction in 1991, judges were recommended to make KHI which refers to 38 books of fiqh as a reference in examining and deciding cases submitted to the Religious Court. When compared between the transformation of
Islamic law into national law, between 1958 and 1991, two things can be found. First, there is an expansion of the Islamic law schools as a reference, second, there is a renewal in a number of aspects. If in 1958 the madzhab used was dominated by the Syafi'i school, then in 1991 the madzhab used was expanded to include five schools, namely, Hanafi, Maliki, Syafi i, Hanbali, and Zhahiri. This means that through reform and transformation, the schools of fiqh are positioned in the same position (musawat al-madzahib). Each of them may be taken as long as it can manifest the purpose of Sharia in family law. This also 
means that the classical sharia is no longer considered sacred, which cannot change. Likewise, the Syafii school of thought is no longer seen as the dominant school of thought. As long as it can realize the goals of sharia, schools outside the mainstream can be used as a reference. This is what Mahfud MD, former chairman of the Constitutional Court meant that the adoption of Islamic law into Indonesian national law takes place through an eclectic process. (Mahfud MD, 2018). The impact of reform and transformation is that the provisions of the figh law used by religious judges must also be synergized with the provisions of material laws in force in Indonesia, such as the law on child protection and the law on the elimination of domestic violence.

\section{The Impact of Reform and Transformation on the Independence of Judges}

Does the reform and transformation of family law in Indonesia have an impact on the lack of independence of judges in exploring and finding
Islamic laws that are more contextual to Indonesian conditions? In other words, will reform and transformation make religious judges at the Religious Courts no longer carry out legal reform? The results of this study indicate that the judges at the Religious Courts are still making reforms through the jurispudence they issue. At least, there have been recorded family law reforms in Indonesia that have been issued through cassation at the Supreme Court. The four reforms are about: 1) inheritance of different religions 2) adopted children of different religions 3) iddah and mut'ah livelihoods 4) the share of shared assets. (Suadi, 2018). At least, there are two family law reforms in Indonesia that were born from the decisions of the constitutional court, namely; the civil rights of a child born out of wedlock to the biological father and the age limit of marriage for men and women. This research found that independence of judges here means independence in exploring and finding Islamic law that is in line with Indonesian culture and constitution.

Table 9. Islamic Law Reform through Cassation in the Supreme Court or Constitutional Court

\begin{tabular}{|l|l|l|}
\hline About & Number of decree and year & Information \\
\hline $\begin{array}{l}\text { Interfaith } \\
\text { inheritance }\end{array}$ & $\begin{array}{l}\text { Supreme Court Decision } \\
\text { Number: 368 K / AG / 1995 }\end{array}$ & $\begin{array}{l}\text { Religious Court of Central Jakarta: } \\
\text { non-Muslim heirs cannot inherit. } \\
\text { High Court and Supreme Court: } \\
\text { non-Muslims can inherit on the } \\
\text { basis of a mandatory will. }\end{array}$ \\
\hline $\begin{array}{l}\text { Adopted children } \\
\text { of different } \\
\text { religions }\end{array}$ & $\begin{array}{l}\text { Supreme Court Decision } \\
\text { Number: } \\
\text { Decision Number 51.K / AG / } \\
1999 \text { and Decision Number } \\
16 . K / \text { AG / 2010 }\end{array}$ & $\begin{array}{l}\text { Provision of compulsory wills to } \\
\text { adopted children and children of } \\
\text { different religions }\end{array}$ \\
\hline $\begin{array}{l}\text { Nafkah iddah and } \\
\text { mut'ah }\end{array}$ & $\begin{array}{l}\text { Decision Number 276.K / AG / } \\
2010\end{array}$ & $\begin{array}{l}\text { Wives earn iddah and mut'ah } \\
\text { livelihoods in a divorce suit }\end{array}$ \\
\hline $\begin{array}{l}\text { Sharing of joint } \\
\text { assets for divorced } \\
\text { husbands and } \\
\text { wives }\end{array}$ & $\begin{array}{l}\text { Decision Number 266.K / AG / } \\
2010\end{array}$ & $\begin{array}{l}\text { In specific case, wife gets 3/4 share } \\
\text { while husband gets 1/4 share. }\end{array}$ \\
$\begin{array}{l}\text { The civil rights of } \\
\text { a child born out of } \\
\text { wedlock to the } \\
\text { biological father }\end{array}$ & $\begin{array}{l}\text { Constitutional Court Decree } \\
\text { Number: 46/PUU-VIII/2010 }\end{array}$ & $\begin{array}{l}\text { In decree, it said that: } \\
\text { "Children born out of wedlock } \\
\text { have a civil relationship with their } \\
\text { mother and their mother's family as } \\
\text { well as with a man as their father } \\
\text { which can be proven based on } \\
\text { science and technology and / or } \\
\text { other evidence by law to have } \\
\text { blood relations, including civil }\end{array}$ \\
\hline
\end{tabular}




\begin{tabular}{|l|l|l|}
\hline & & $\begin{array}{l}\text { relations with their father's } \\
\text { family"; }\end{array}$ \\
\hline $\begin{array}{l}\text { The age limit of } \\
\text { marriage for men } \\
\text { and women }\end{array}$ & $\begin{array}{l}\text { Constitutional Court Decree } \\
\text { Number: 22/PUU-XV /2017 }\end{array}$ & $\begin{array}{l}\text { canceling the minimum age of } \\
\text { marriage for women, 16 years, so } \\
\text { that for both women and men, the } \\
\text { minimum age of marriage is 19 } \\
\text { years }\end{array}$ \\
\hline
\end{tabular}

\section{Conclusion}

This study found a variety of models in the exploration, practice and reform of family law in the Islamic world. Variations can also be found when the Muslim world carries out the process of transforming family law into national law. The impact of the reform and transformation of family law in Indonesia is that the classical fiqh books that were originally used as the main reference and are considered sacred, have lost their sanctity. This study concludes that the reform and transformation of family law in Indonesia does not reduce the independence of religious judges in exploring and finding more contextual Islamic law as evidenced by the emergence of a number of reforms that have emerged from a number of jurisprudences.

In order for reform and transformation to support the formation of Indonesian fiqh, the rulings of religious judges must reflect the spirit of the Indonesian national legal system. This means that the rulings of religious courts as a product of Indonesian fiqh must be synergized with the principles and objectives of national law. In other words, the decision of the religious court must not contradict the basic principles that have been stated in the Indonesian constitution. Because, substantively, Islamic law has been transformed into the constitution. Therefore, for Indonesian Muslims, demands for faith and demands for the constitution must be synergized.

In the Indonesian context, religious law and state law can be distinguished but cannot be separated. Therefore, the choice is not to take one of the various religious laws but to choose which of the religious laws (fiqh) is the most appropriate to Indonesian conditions. To protect the objectives of Islamic law in family law which includes protection of property (al-mal), soul (al-nafs) and descendants / family (al-nasl), the normative formulations contained in classical fiqh can change or be changed with new formulations. Because the normative formulation in the maqashid sharia hierarchy falls into the category of hajiyat, while the protection of these three things is dlaruriyat .

Given that Islamic law has historically developed outside state institutions, codification and legislation for family law is not something urgent. Family law in Indonesia can develop through jurisprudence, along with the development of law in Indonesia as a whole. In order for family life problems to be resolved through one institution, the idea of the need for an integrated family justice system that can examine and resolve various problems related to family matters, such as domestic violence or under age marriage needs to be supported and continued.

\section{References}

[1] Abdul Hakim, Atang (2018), "Transformasi Fiqh Ke dalam Peraturan Perundang-Undangan", dalam Asep S. Muhtadi, ed. Transformsi Islam di Indonesia Kontemporer, LEKKAS (Lembaga Kajian Komunikasi dan Sosial), Bandung, 2018, hlm. 60-63.

[2] Abou El Fadl, Khaled, ( 2004), Islam and The Challenge of Democracy; A Boston Review Book, Princeton University Press, page 34 .

[3] Ash Shiddieqy, Hasbi (1975). Filsafat Hukum Islam. Jakarta, Bulan Bintang.

[4] Abdul Rauf, Imam Feisal ed.(2015), Defining Islamic Statehood; Measuring and Indexing Contemporary Muslim States-Palgrave Macmillan UK, 2015.p. 58

[5] Abu Daud, juz II, tanpa tahun, hal 240; Misykat, hal 25, Kitabul Ilmi)

[6] Alam, Lubna A, 2007. Keeping The State 
Out: The Separation of Law and State in Classical Islamic Law, Michigan Law Review, April 2007, Vol. 105 Is-sue 6, p1255

[7] Auda, Jasser (2007). Maqasid al-Shari'ah as Philoso- phy of Islamic Law, A Systems Approach, London, Washington: The International Institute of Islamic Thought

[8] Bakry, Hasbullah, (1984), Bunga Rampai Tentang Islam, Negara dan Hukum, Jakarta, Pedoman Ilmu Jaya, 1984

[9] Black, Ann, Esmaeili, Hussein and Hosen, Nadirsyah, ( 2013). Modern Perspective on Islamic Law, UK: Edward Elgar Publishing Limited

[10] Dobinson, Ian and Johns, Francis (2004) Qualitative Legal Research, in Mike McConville and Wing Hong Chui, ed., Research Methods for Law, Edinburgh University Press, 2007, p. 20

[11] Hadi, Samsul, (2018), PUTUSAN MK NO.22 /PUU-XV /2017 TENTANG PERMOHONAN JUDICIAL REVIEW PASAL 7 AYAT (1) UU NO. 1 TAHUN 1974 TENTANG USIA PERKAWINAN DALAM PERSPEKTIF MASLAHAH, Al-Ah wa l, Vol. 11, No. 2, Tahun $2018 \mathrm{M} / 1439 \mathrm{H}$

[12] Hosseini, Ziba Mir et.el., (2013) Gender and Equality in Muslim Family Law: Justice and Ethics in the Islamic Legal Process-I.B. Tauris (2013) page 143

[13] Huda, Miftahul (2017), RAGAM BANGUNAN PERUNDANGUNDANGAN HUKUM KELUARGA DI NEGERA-NEGARA MUSLIM MODERN (Kajian Tipologis), AlManahij, Jurnal Kajian Hukum Islam, vol.XI No.1, Juni 2017

[14] Ibn Qayyim, I'lam al-Muwaqi'in, jilid III, Bairut Dar al-Kutub al-Ilmia, hlm. 37.

[15] Lubis, Nur Ahmad Fadhil, (1997)."Islamic Legal Literature and Substantive Law in Indonesia", Studia Islamika, Indonesian Journal for Islamic Studies, Volume 4, Number 4,1997. Pp.33 -92.
[16] Mahfud MD, Moch, (2018) Hukum Islam dalam Hukum Nasional, Kompas, Jum'at, 22 Juni 2018

[17] Mahmood, Tahir (1987), Personal Law in Islamic Countries, Academy of Law and Religion, Times Press, New Delhi,1987

[18] Mas'udi, Masdar Farid, (2011) "Islam Indonesia vs NKRI", makalah disajikan dalam rangka bedah buku "SYARAH UUD 1945: Perspektif Islam," di UIN Sunan Gunung Djati Bandung, Kamis 30 Juni 2011

[19] Nurrohman, Abdullah Safe'i, Tatang Astarudin, Mohamad Sar'an, (2018) Transformasi dan integrasi hukum Islam dalam hukum nasional: Kajian atas model, problem dan reformasi hukum Islam di Indonesia. UIN Bandung, Bandung.

[20] Otto, Jan Michiel ed., (2010), Sharia Incorporated: A Comparative Overview of the Legal Systems of Twelve Muslim Countries in Past and Present, Leiden University Press, 2010, hal. 25, 26.

[21] Praja, Juhaya S., (2009.) Teori-teori Hukum Islam: Suatu Telaah Perbandingan dengan Pendekatan Filsa- fat, Bandung, Program Pascasarjana Universitas Islam Negeri (UIN)

[22] Rehman,S and Askari, H. (2010) "How Islamic are Islamic Countries". Global Economy Journal, 10 (2),1-27.

[23] Ridwan, Ahmad Hasan. (2013), EPISTEMOLOGI HUKUM ISLAM (Jejak Hermeneutika M. Syahrur dan N.H.Abu Zaid), makalah, disampaikan dalam diskusi Madrasah Malem Rebo, pada tanggal 12 November 2013.

[24] Suadi, Amran, (2018), The Role of The Supreme Court in Developing Islamic Law in Indonesia, paper presented as keynote speech at the International Conference on Humanity, Law and Sharia (ICHlaSH) held by Syariah Faculty, The State Institute for Islamic Studies, Batusangkar, on Wednesday, November 14, 2018, in Batusangkar West Sumatra.

[25] Schacht, Joseph, (1983) An Introduction to Islamic Law, Oxford, University Press. 
[26] Soekanto, Soerjono dan Mamudji, Sri (2001) Penelitian Hukum Normatif: Suatu Tinjauan Singkat, edisi 1, cet.v, (Jakarta: PT Raja Grafindo Persada, 2001), p.13-14

[27] Syarif, Nurrohman, (2019) "Transformation and Reformation of Islamic Criminal Law; The Study on Aceh Qanun Jinayat and Its Impact To Woman and Non-Muslim, Jurnal Dinamika Hukum, Volume 19 Issue 2, Mei 2019

[28] Syarif, Nurrohman, (2016) "Syariat Islam dalam Perspektif Negara Hukum berdasar Pancasila", Pandecta; Jurnal Penelitian Ilmu Hukum (Research Law Journal), Volume 11. Nomor 2. December 2016 ,

[29] Syarif, Nurrohman, (2019) "Sharia and Democracy: Efforts to Synergize The Demands of Faith with The Legal System in Indonesia ', $44^{\text {th }}$ International Scientific Conference on Economic and Social Development, Book of Proceedings, editors: Mila Nadrljanski at.al, Split, 1920 September 2019. Page 347-359.

[30] Tibi, Bassam, (2010) Islam and Islamism, Yale University Press, London, 2012

\section{Website}

[31] http://dinamikahukum.fh.unsoed.ac.id/inde x.php/JDH/article/view/2373/654

[32] https://journal.unnes.ac.id/nju/index.php/p andecta/article/view/7829/6325

[33] http://www.esd-conference.com

[34] http://digilib.uinsgd.ac.id/24698/

\section{Short CV of Nurrohman Syarif}

Nurrohman, born in Tegal, August 17, 1958. His father is HM Syarif. He sometimes uses Nurrohman Syarif as the name of his publication. He obtained a doctorate in Islamic studies from the Syarif Hidayatullah State Islamic University (UIN), Jakarta. Now he is an associate professor at the State Islamic University (UIN) Sunan Gunung Djati, Bandung. He teaches Islamic Law, especially related to politics (Fiqh Siyasah). His area of interest is the study of the relationship between religion, politics, law and economics in Islam. Apart from being the head of the Master of Family Law study program at UIN Sujan Gunung Djati, Bandung, he is also a member of the Associate Council for Research in Values and Philosophy (CRVP), Washington DC. 